\title{
PERAN PENYULUH PERTANIAN LAPANGAN (PPL) DALAM KEGIATAN KELOMPOK TANI DI KECAMATAN GERUNG KABUPATEN LOMBOK BARAT
}

\section{THE ROLE OF FILED AGRICULTURAL EXTENTIONS WORKS IN THE ACTIVITIES OF FARMER GROUPS AT GERUNG WEST LOMBOK REGENCY}

\author{
Mis'ah ${ }^{1}$, Lalu Wiresapta Karyadi ${ }^{2}$, Siti Nurjannah ${ }^{3}$ \\ ${ }^{1}$ Mahasiswa Program Studi Agribisnis Jurusan Sosial Ekonomi Pertanian Universitas Mataram \\ ${ }^{2,3}$ Dosen Program Studi Agribisnis Jurusan Sosial Ekonomi Pertanian Universitas Mataram \\ Email: misahajja8@gmail.com
}

\begin{abstract}
ABSTRAK
Tujuan penelitian ini adalah (1) mengetahui peran penyuluh pertanian lapangan (PPL) dalam kegiatan kelompok tani (2) mengetahui kendala-kendala yang dihadapi penyuluh pertanian lapangan (PPL) dalam kegiatan kelompok tani di Kecamatan Gerung Kabupaten Lombok Barat. Penelitian ini menggunakan metode deskriptif. Unit analisis dalam penelitian ini adalah petani yang tergabung dalam kelompok tani dan penyuluh yang membina kelompok tani tersebut. Lokasi penelitian ditetapkan secara "purposive sampeling. Penentuan responden ditentukan secara purposive sampling untuk responden penyuluh dan pengurus kelompok, untuk anggota kelompok ditentukan secara quota sampling sebanyak 3 orang dari masing-masing kelompok. Pemilihan responden anggota kelompok ditentukan secara random sampling. Analisis data dalam penelitian ini menggunakan skoring. Hasil penelitian menunjukkan (1) penyuluh pertanian lapangan berperan dalam kegiatan kelompok tani dengan modus skor gabungan 67 untuk peran sebagai fasilitator diperoleh skor sebesar 28, untuk motivator diperoleh skor sebesar 27 dan organisator diperoleh skor sebesar 12, (2) kurangnya modal, rendahnya sumber daya petani dan wilayah kerja penyuluh pertanian lapangan yang luas.
\end{abstract}

Kata kunci: penyuluh pertanian lapangan (PPL), kegiatan, peran.

\begin{abstract}
The purpose of this study is to (1) know the role of agricultural extension officer filed in farmers group activities (2) know the constraints facing the agricultural filed extension officer in the activities of the farmers group ad west Lombok Regency. This research uses descriptive method. The unit of analysis in this researh are farmers and extension officer who buid the farmers group. Location of reaserch set by purposive sampling. Determination of the respondent's purposive sampling basis determined for respondent extension officr and administrators group, to mamber of the group specified in quota sampling as much as 3 people from each group. The election of the respondent group members determined in random samling. Data analysis in this study uses the skoring. The reasuld showed (1) agricurtule filed extension officer play a role in the activities of the group of farmres with a combined score of 67, mode fore a role as a facilitator obtained score of 28 , to motivator retrieved score of 27 and fore the role of organizer of the obtained score of 12, (2) lack of capital, low resource farmers and agricultural extension officer work areas of the filed.
\end{abstract}

Keywords: agricultural extension filed, activities, role. 


\section{PENDAHULUAN}

Sektor pertanian merupakan sektor strategis dalam pembanguna nasional. Sektor pertanian selalu masuk tiga besar dalam membentuk nilai PDB (Septiadi, 2019). Besarnya peran sektor pertanian tidak lepas dari peran produktifitas pertanian di Indonesia yang cukup mengesankan. Peningkatan produktifitas banyak didorong dengan adanya kegiatan penyuluhan pertanian. Penyuluhan pertanian memiliki peran penting untuk meningkatkan pengetahuan dan keterampilan petani. Sebagaimana dimandatkan dalam Peranturan Mentri Pertanian Nomor 82 tahun 2013. Penyuluh berperanan sebagai pembimbing, sebagaiteknisi, sebagai agen penghubung, sebagai organisator dan dinamisator yang mempengaruhi kelompok-kelompoktani. Penyuluh pertanian harus merupakan seseorang yang berkompeten dibidang pertanian dan dapat berkomunikasi secara efektif dan cepat tanggap dalam menghadapi setiap permasalahan dan pertanyaan yang nantinya akan diajukan oleh para petani. Adanya peranan Penyuluh dalam pembinaan kelompok tani akan sangat membantu terjadinya hubungan interpersonal antar keduanya. Sehingga diharapkan proses transfer informasi maupun adopsi inovasi akan berjalan dengan lancar yang pada akhirnya mampu meningkatkan kinerja kelompok tani serta mengubah kesejahteraan petani menjadi lebih baik (Anonim, 2012).

Di Provinsi NTB tenaga penyuluh pertanian mencapai 1.978 penyuluh yang tersebar diseluruh kabupaten, kota dan desa, sedangkan di Kabupaten Lombok Barat terdapat tenaga penyuluh sebanyak 278 tenaga penyuluh yang tersebar di 122 desa (BPPSDMP, 2016). Di Kecamatan Gerung terdapat 16 orang penyuluh dimana, 5 orang tenaga penyuluh harian lepas (THL), dan 11 orang penyuluh PNS yang membina 216 kelompok-kelompok tani (UPTD GERUNG, 2017). Penyuluh dituntut untuk berperan aktif dalam membina kelompok tani memotivasi petani agar minat kerja sama dan partisipasinya tinggi untuk mengembangkan kelompok tani yang kondusif agar tujuan yang ingin dicapai terwujud. Maka perlu dilakukan suatu penelitian tentang Peran penyuluh Pertanian Lapangan (PPL) dalam Kegiatan Kelompok Tani di Kecamatan Gerung Kabupaten Lombok Barat. Untuk mengetahui peran penyuluh dalam kegiatan kelompok tani

\section{METODE PENELITIAN}

Metode yang digunakan dalam penelitian ini adalah metode deskriptif dengan teknik survei (survey). Sugiono (2012) menjelaskan metode survei digunakan untuk mendapatkan data dari tempat tertentu yang alamiah (bukan buatan), tetapi peneliti melakukan perlakuan dalam pengumpulan data, misalnya dengan mengedarkan kuesioner, test, wawancara tersrtuktur dan sebagainya. Unit analisis dalam penelitian ini adalah petani yang tergabung dalam kelompok tani dan penyuluh pertanian yang membina kelompok tani di Kecamatan Gerung Kabupaten Lombok Barat. Lokasi penelitian ditetapkan 3 desa/kelurahan secara purposive sampling atas pertimbangan desa yang terpilih adalah desa yang memiliki jumlah kelompok tani paling banyak. Penentuan responden ditentukan secara purposive sampling dimana responden terdiri dari 3 orang penyuluh, setiap desa dipilih masing-masing 1 orang responden penyuluh dengan alasan mereka bertugas membina kelompok tani di desa sampel, dan 2 orang pengurus kelompok tani (ketua, serketaris atau bendahara). Anggota kelompok ditentukan secara quota sampling sebanyak 3 orang dari masingmasing kelompok. Pemilihan responden anggota kelompok ditentukan secara random sampling. Sehingga total responden 48 orang.

Jenis data yang digunakan dalam penelitian ini adalah data kualitatif dan data kuantitatif. Variabel yang diteliti yakni peran penyuluh sebagai fasilitator, motivator, organisator dan kendala-kendala yang dihadapi penyuluh pertanian lapangan (PPL) dalam kegiatan kelompok tani. Pengukuran variabel peran penyuluh pertanian lapangan dalam kegiatan kelompok tani akan di ukur dari hasil wawancara dengan 45 orang petani dengan sistem skoring, dimana untuk setiap pertanyaan pada setiap indikator diberikan skor terendah (1), skor sedang (2), dan skor tertinggi (3). Pengukuran variabel kendala-kendala yang di hadapi penyuluh pertanian lapangan (PPL) dalam menjalankan perannya sebagai fasilitator, motivator, dan organisator dalam kegiatan kelompok tani dilakukan dengan wawancara langsung dan mendalam kepada penyuluh kemudian di interpretasikan.

Analisis dapat dilakukan dengan cara menghitung atau menjumlahkan skor setiap komponen kemudian dihitung skor gabungannya, sehingga akan diketahui jumlah skor yang tercapai yang termasuk interval skor dalam katagori tertentu. Untu kmengetahui interval skor dengan mengacu pada renge skor komulatif (SK) dihitung menggunakan rumus sebagai berikut:

Skor maksimum $=\sum$ item $\times \sum$ skor tertinggi $=25 \times 3=75$

Skor minimum $=\sum$ item $\times \sum$ skor terendah $=25 \times 1=25$ 
Selanjutnya untuk mengetahui interval skor dengan mengacu pada range skor komulatif (SK) dihitung menggunakan rumus sebagai berikut:

$$
\begin{aligned}
\text { Interval Skor (IS) } & =\frac{\text { Skor Maksimum }- \text { Skor Minimum }}{\text { Jumlah Katagori }} \\
& i \frac{75-25}{3} \\
& =16
\end{aligned}
$$

Setelah skor diketahui keputusannya adalah sebagai berikut:

Tabel 1. Interval skor pengukuran peran penyuluh pertanian lapangan (PPL) dalam kegiatan kelompok tani di Kecamatan Gerung Kabupaten Lombok Barat.

\begin{tabular}{lll}
\hline NO & Katagori & Interval Skor \\
\hline 1 & Tidak Berperan & $25-41$ \\
2 & Kurang Berperan & $42-58$ \\
3 & Berperan & $59-75$ \\
\hline
\end{tabular}

\section{HASIL DAN PEMBAHASAN}

\section{Peran Penyuluh Pertanian Lapangan (PPL) dalam Kegiatan Kelompok Tani}

Hasil dari penelitian ini menunjukkan bahwa peran Penyuluh Pertanian Lapangan (PPL) dalam kegiatan kelompok tani berada pada kriteria berperan atau dengan kata lain penyuluh telah menjalankan tugas dan fungsinya dengan baik. Secara lengkap ditunjukkan pada tabel berikut:

Tabel 1.1 Peran Penyuluh Pertanian Lapangan dalam Kegiatan Kelompok Tani di Kecamatan Gerung Kabupaten Lombok Barat Tahun 2018

\begin{tabular}{llcl}
\hline No & Uraian & Modus Skor Gabungan & Katagori \\
\hline 1 & Fasilitator & 28 & Berperan \\
2 & Motivator & 27 & Berperan \\
3 & Organisator & 12 & Berperan \\
\hline Modus Skor Gabungan & 67 & Berperan \\
\hline
\end{tabular}

Sumber: Data Primer Diolah, 2018

Berdasarkan Tabel 1.1 di atas dapat dilihat bahwa, modus skor peran penyuluh pertanian lapangan (PPL) dalam kegiatan kelompok tani di Kecamatan Gerung Kabupaten Lombok Barat termasuk dalam katagori berperan dengan modus skor gabungan yaitu 67. Faktor ini didukung dengan jumlah responden yang menyatakan penyuluh berperan sebanayak 35 orang dan cukup berperan Secara rinci pencapaian skor dari variabel-variabel pada tabel diatas dilakukan pengukuran terhadap indikator-indikator pada setiap variabel. Adapun penjelasannya sebagai berikut:

\section{Peran Penyuluh Sebgai Fasilitator}

Peran utama seorang fasilitator adalah menjadi pemadu proses. Ia akan selalu mencoba proses yang terbuka, inklusif, dan adil sehingga setiap individu berpartisipasi secara seimbang. Fasilitator juga menciptakan ruang aman dimana semua pihak sungguh-sungguh berpartisipasi. Selain sebagai pemandu proses, fasilitator memiliki peran penting lainnya yaitu sebgai Tool Giver atau pemberi alat bantu. Selain itu juga berperan sebagai Process Educator atau pendidik proses (Najiah, 2014). Sebaran petani/responden mengenai peran penyuluh pertanian lapangan (PPL) dalam kegiatan kelompok tani bedasarkan pada pernyataan- pernyataan (kriteria) disajikan dalam dapat dilihat pada Tabel 1.2. berikut: 
Tabel 1.2. Sebaran Petani Berdasarkan Skor Peran Penyuluh Pertanian Lapangan (PPL) Sebagai Fasilitator dalam Kegiatan Kelompok Tani di Kecamatan Gerung Kabupaten Lombok Barat Tahun 2018

\begin{tabular}{|c|c|c|c|c|c|c|c|c|}
\hline \multirow[b]{2}{*}{ No } & \multirow[b]{2}{*}{ Kriteria } & \multicolumn{4}{|c|}{ Sebaran Responden Berdasarkan Skor } & & \multicolumn{2}{|r|}{ Katagori } \\
\hline & & $\begin{array}{r}\text { Tidak } \\
\text { Berperan } \\
\end{array}$ & $\%$ & $\begin{array}{r}\text { Cukup } \\
\text { Berperan }\end{array}$ & $\%$ & Berperan & $\%$ & \\
\hline 1 & $\begin{array}{l}\text { Membantu petani } \\
\text { memperoleh informasi } \\
\text { pertanian }\end{array}$ & 1 & 2,2 & 15 & 33,3 & 29 & 64,5 & Baik \\
\hline 2 & Melakukan demplot & 8 & 17,8 & 8 & 17,8 & 29 & 64,5 & Baik \\
\hline 3 & $\begin{array}{l}\text { Melakukan studi } \\
\text { Banding }\end{array}$ & 33 & 73,3 & 3 & 6,7 & 9 & 20 & $\begin{array}{l}\text { Tidak } \\
\text { Baik }\end{array}$ \\
\hline 4 & $\begin{array}{l}\text { Membantu kerjasama } \\
\text { dengan pihak lain } \\
\text { (KUD,instansi terkait) }\end{array}$ & 5 & 11,1 & 0 & 0 & 40 & 88,9 & Baik \\
\hline 5 & $\begin{array}{l}\text { Membantu menganalisis } \\
\text { usaha } \\
\text { tani }\end{array}$ & 6 & 13,3 & 8 & 17,8 & 31 & 68,9 & Baik \\
\hline 6 & $\begin{array}{l}\text { Membantu menyususn } \\
\text { RDK/RDKK }\end{array}$ & 1 & 2,2 & 4 & 8,9 & 40 & 88,9 & Baik \\
\hline 7 & $\begin{array}{l}\text { Msembantu } \\
\text { menyususn rencana } \\
\text { evaluasi }\end{array}$ & 5 & 11,1 & 10 & 22,2 & 30 & 66,7 & Baik \\
\hline 8 & $\begin{array}{l}\text { Menyediakan sarana dan } \\
\text { sumber belajar yang } \\
\text { memadai }\end{array}$ & 10 & 22,2 & 21 & 46,7 & 14 & 31,1 & Cukup Baik \\
\hline 9 & $\begin{array}{l}\text { Memberikan materi } \\
\text { sesuai kebutuhan }\end{array}$ & 2 & 4,4 & 8 & 17,8 & 35 & 77,8 & Baik \\
\hline 10 & $\begin{array}{l}\text { Membantu proses } \\
\text { interaksi dalam kelompok }\end{array}$ & 6 & 13,3 & 13 & 28,9 & 26 & 57,8 & Baik \\
\hline
\end{tabular}

Sumber: Data Primer Diolah (2018)

Berdasarkan Tabel 1.2. di atas terlihat bahwa sebaran petani yang menilai peran penyuluhpertanian lapangan (PPL) sebagai fasilitator dalam kegiatan kelompok tani berada pada katagori baik. Selanjutnya dari sepuluh kriteria tersebut ternyata peran penyuluh dalam membantu menjalin kerjasama dan membantu menyususn RDK/RDKK termasuk katagori baik dengan sebaran petani paling banyak yakni masing-masing sebanyak 40 orang dengan persentase $88,9 \%$, sedangkan sebaran petani paling sedikit 9 orang dengan persentase $20 \%$ untuk katagori baik terdapat pada kriteria peran penyuluh dalam melakukan study banding.

Hasil penelitian menunjukkan bahwa penyuluh berperan dalam membantu petani/kelompok kerja sama dengan pihak lain (Kelompok lain, KUD, bank, penyedia saprodi instansi terkait dan lainnya). Lebih lanjutnya dapat dilihat pada Tabel 1.2 di atas. Sebagian besar 40 orang $(88,9 \%)$ responden menyatakan bahwa penyuluh membantu petani/kelompok kerja sama dengan pihak lain (Kelompok lain, KUD, bank, penyedia saprodi instansi terkait dan lainnya), petani menyatakan bahwa penyuluh memfasilitasi proses dari mulai penentuan mitra(Kelompok lain, KUD, bank, penyedia saprodi instansi terkait dan lainnya) hingga kesepakatan terbentuk. Menurut (Anonim, 2016) dengan kerjasama tersebut petani dapat saling tukar pengalaman antar kelompok, mendapatkan informasi baru, untuk memperkuat kelompok tani baik dari segi administrasi organisasi maupun usaha kelompok dan untuk memudahkan petani dalam mengakses kebutuhan usaha tani, sementara itu 5 orang $(11,1 \%)$ menyatakan penyuluh tidak membantu petani/kelompok kerja sama dengan pihak lain (Kelompok lain, KUD, bank, penyedia saprodi instansi terkait dan lainnya) hal ini terjadi pada salah satu kelompok kelompok tersebut tidak aktif atau mati suri.

Hasil penelitian menunjukaan bahwa penyuluh berperan dalam membantu petani menyusun RDK/RDKK.Lebih lanjut dapat dilihat pada Tabel 1.2 di atas. Sebagian besar responen petani 40 orang $(88,9 \%)$ menyatakan bahwa penyuluh aktif dalam membantu petani menyusun RDK/RDKK. Responden menyatakan bahwa penyuluh selalu membantu dan memfasilitasi petani saat peoses pembuatan RDK/RDKK hal ini dapat dilihat dari jumlah kehadiran penyuluh saat penyususnan RDK/RDKK penyuluh selalu hadir saat pembuatan RDK/RDKK yakni setiap periode, dandikarenakan tugas penyuluh hal ini sesuai dengan pendapat Siti Nurjanah, 2108 (dalam tabloid sinar tani) penyusunan RDK/RDKK merupakan kegiatan strategis yang harus dilaksanakan secara tepat dan tepat waktu, sehingga dapat membentuk gerakan untuk membangun dengan RDK/RDKK 
dengan benar dan sesuai dengan kebutuhan petani. Mengingat kemampuan petani dalam menyusun RDK/RDKK masih terbatas, maka penyuluh pertanian perlu membimbing dan mendampingi kelompok tani. Supaya RDK/RDKK yang dibuat sesuai, sedangkan 4 orang (8,9\%) menyatakan bahwa penyuluh cukup aktif dalam membantu petani menyusun RDK/RDKK. Penyuluh mengetahui bahwa petani menyusun RDK/RDKK akan tetapi penyuluh tidak melibatkan diri saat proses pembuatan dan menyerahkan semuanya kepada pengurus penyuluh hanya mengesahkan saja, dan 1 orang $(2 \%)$ responden menyatakan penyuluh tidak aktif dalam membantu petani menyusun RDK/RDKK hal ini terjadi karena petani tidak hadir saat proses pembuatan.

Hasil penelitian menunjukaan bahwa penyuluh tidak berperan dalam mengikut sertakan petani studi banding. Lebih lanjut dapat dilihat pada Tabel 1.2 di atas. Sebagian besar responden petani 33 orang (73,3\%) menyatakan bahwa penyuluh tidak mengikut sertakan petani studi banding, hal ini dikarenakan kelompok yang ikut studi banding adalah kelompok yang sudah maju (kelas madya/utama) dan hanya pengurus yang diprioritaskan untuk ikut karena wawasan lebih luas dan tingkat pemahamannya lebih tinggi dibandingkan anggota, sedangkan 9 orang $(20 \%)$ menyatakan penyuluh mengajak petani studi banding karena merupakn ketua dari kelompok dan pengurus aktif, dan 3 orang $(6,7 \%)$ menyatakan penyuluh kadang-kadang mengikut sertakan petani studi banding karena menyesuaikan dengan program dan kebutuhan dari program.

\section{Peran Penyuluh Sebagai Motivator}

Indonesia adalah negara yang berbasis pertanian. Hal ini didukung oleh letak geografis yang berada pada jalur katulistiwa, dimana sinar matahari diperoleh sepanjang tahun. Pertanian Indonesia saat ini bekembang lambat salah satu penyebabnya ialah semakin terbatasnya lahan pertanian di Indonesia. Selain itu, anggapan masyarakat bahwa bertani merupakan pekerjaan kaum kelas bawah juga juga berperan menghambat perkembangan pertanian di Indonesia. Untuk itu dibutuhkan penyuluh sebagai motivator dan rekan yang membangun pertanian Indonesia. Sebaran petani/responden mengenai peran penyuluh pertanian lapangan (PPL) sebagai motivator dalam kegiatan kelompok tani berdasarkan pada pernyataan-pernyataan (kriteria) dapat dilihat pada Tabel 1.3 berikut.

Tabel 1.3. Sebaran Petani Berdasarkan Skor Peran Penyuluh Pertanian Lapangan (PPL) Sebagai Motivator dalam Kegiatan Kelompok Tani di Kecamatan Gerung Kabupaten Lombok Barat Tahun 2018

\begin{tabular}{|c|c|c|c|c|c|c|c|c|}
\hline \multirow[b]{2}{*}{ No } & \multirow[b]{2}{*}{ Kriteria } & \multicolumn{6}{|c|}{ Sebaran Responden Berdasarkan Skor } & \multirow[t]{2}{*}{ Katagori } \\
\hline & & $\begin{array}{l}\text { Tidak } \\
\text { Berperan }\end{array}$ & $\%$ & $\begin{array}{l}\text { Cukup } \\
\text { Berperan }\end{array}$ & $\%$ & Berperan & $\%$ & \\
\hline 1 & $\begin{array}{l}\text { Melakukan bimbingan dalam } \\
\text { penerapan teknologi }\end{array}$ & 2 & 4,4 & 14 & 31,1 & 29 & 64,4 & Baik \\
\hline 2 & $\begin{array}{l}\text { Mendorong petani/kelompok } \\
\text { dalam menyelesaikan } \\
\text { masalah yang dihadapi }\end{array}$ & 3 & 6,7 & 19 & 42,2 & 23 & 51,1 & Baik \\
\hline 3 & $\begin{array}{l}\text { Mendorong petani } \\
\text { untuk melakuakn diskusi }\end{array}$ & 2 & 4,4 & 8 & 17,8 & 35 & 77,8 & Baik \\
\hline 4 & $\begin{array}{l}\text { Membantu } \\
\text { merumuskan solusi }\end{array}$ & 0 & 0 & 10 & 22,2 & 35 & 77,8 & Baik \\
\hline 5 & $\begin{array}{l}\text { Membantu } \\
\text { menyediakan alsintan }\end{array}$ & 0 & 0 & 8 & 17,8 & 37 & 82,2 & Baik \\
\hline 6 & $\begin{array}{l}\text { Membantu menyediakan } \\
\text { saprodi }\end{array}$ & 0 & 0 & 0 & 0 & 45 & 100 & Baik \\
\hline 7 & $\begin{array}{l}\text { Memberikan informasi dan } \\
\text { inovasi baru }\end{array}$ & 0 & 0 & 0 & 0 & 45 & 100 & Baik \\
\hline 8 & $\begin{array}{l}\text { Mengajak petani dalam } \\
\text { berbagai kegiatan kelompok }\end{array}$ & 8 & 17,8 & 11 & 24,4 & 26 & 57,8 & Baik \\
\hline 9 & $\begin{array}{l}\text { Membantu mengelola } \\
\text { keuangan kelompok }\end{array}$ & 20 & 44,4 & 4 & 8,9 & 21 & 46,7 & Baik \\
\hline
\end{tabular}

Sumber: Data Primer Diolah, 2018

Berdasarkan Tabel 1.3 di atas terlihat bahwa sebaran petani yang menilai peran penyuluh pertanian lapangan (PPL) sebagai motivator dalam kegiatan kelompok tani berada pada katagori baik. Selanjutnya dari sembilan kriteria tersebut ternyata peran penyuluh dalam membantu menyediakan saprodi dan memberikan informasi dan inovasi baru termasuk katagori baik dengan sebaran petani paling banyak yakni masing-masing sebanyak 45 orang dengan persentase 100\%, sedangkan sebaran petani paling sedikit 21 orang dengan 
persentase $46,7 \%$ untuk katagori baik terdapat pada kriteria peran penyuluh dalam membantu mengelola keuangan kelompok. Untuk lebih jelasnya kriteria dijelaskan sebagai berikut.

Hasil penelitian menunjukkan penyuluh berperan dalam menyediakan saprodi (sarana produksi). Lebih lanjut dilihat dari sebaran petani yang menilai peran penyuluh dalam menyediakan saprodi (sarana produksi) seperti tergambar pada Tabel 1.3 di atas. Semua responden 45 orang (100\%) sepakat bahwa penyuluh membantu dalam menyediakan saprodi (sarana produksi). Petani menyatakan bahwa setiap musim tanam petani mendapatkan bibit, dan pada saat usia tanaman sudah sudah tumbuh dan siap dipupuk petani mendapatkan pupuk dari penyuluh, akan tetapi bantuan tersebut tidak selalu diberi percuma. Petani harus membayar/membeli saprodi (sarana produksi) tersebut dengan harga yang lebih murah atau harga subsidi. Penyuluh merupakan agen penghubung antara petani dengan lembaga pemerintah.

Hasil penelitian menunjukkan penyuluh berperan dalam memberikan inovasi baru. Lebih lanjut dilihat dari sebaran petani yang menilai peran penyuluh dalam memberikan inovasi baru, seperti tergambar pada Tabel 1.3 di atas. Semua responden 45 orang (100\%) menyatakan bahwa penyuluh selalu memberikan inovasi baru hal tersebut dikarenakan tugas penyuluh sebgai pendamping sebagian besar inovasi yang diterima oleh petani/kelompok melalui perantara penyuluh dan penyuluh sebagai penyampai inovasi untuk meningkatkan wawasan dan menjadikan petani lebih baik dan maju dalam mengelola usaha taninya.

Hasil penelitian menunjukkan penyuluh berperan dalam mendorong petani untuk mengelola keuangan kelompok. Lebih lanjut dilihat dari sebaran petani yang menilai peran penyuluh dalam mendorong petani untuk mengelola keuangan kelompok seperti tergambar pada Tabel 1.3 di atas. Sebanyak 21 orang (46,7\%) menyatakan bahwa penyuluh aktifdalam mendorong petani untuk mengelola keuangan kelompok. Menurut petani penyuluh sudah membantu mendorong petani untuk mengelola keuangan kelompok dengan cara mengajarkan petani atau pengurus kelompok membuat buku keuangan kelompok dan mengajarkan cara mengelola keuangan tersebut. Hal ini dilakukan untuk menstabilkan pengelolaan kas kelompok dan untuk mendorong petani mengeluarkan iuran rutin kelompok, sedangkan 20 orang $(44,4 \%)$ menyatakan bahwa penyuluh tidak aktif dalam mendorong petani untuk mengelola keuangan kelompok. Hal ini dikarenkan belum terbentuknya kesepakatan iuran kelompok, sementara itu 4 orang $(8,9 \%)$ menyatakan penyuluh cukup aktif dalam mendorong petani untuk mengelola keuangan kelompok. Petani menyatakan bahwa penyuluh hanya memberitahu untuk mengelola keuangan kelompok dan menerangkan secara rinci bagaimana keuangan kelompok itu dikelola supaya stabil akan tetapi penyuluh tidak ikut dalam proses pembuatan atau pengelolaannya hal tersebut dikarenakan agar kelompok dapat mengelola keuangannya sendiri dan menjadikan kelompok mandiri.

\section{Peran Penyuluh Sebagai Organisator}

Berdasarkan Tabel 1.4 peran penyuluh pertanian lapangan (PPL) dalam kegiatan kelompok tani di Kecamatan Gerung Kabupaten Lombok Barat sebagai organisator dalam penelitian ini berada pada katagori cukup baik dan penyuluh cukup berperan. Berdasarkan pernyataan-pernyataan petani, hal ini dikarenakan penyuluh sudah cukup mampu menumbuhkan rasa kebersamaan antar petani kelompok atau antar kelompok lain sehingga antusias mayarakat untuk membentuk kelompok cukup besar. Terlihat dari cukup banyaknya jumlah anggota dalam satu kelompok tani dan penyuluh melibatkan diri dalam pembentukannya. Sehingga dapat dilihat bahwa masyarakat petani dan penyuluh memiliki keinginan untuk memperbaiki kegiatan usahtaninya melalui kelembagaan pertanian atau kelompok tani. Tabel 1.4 berikut menjelaskan secara rinci penyebab penyuluh cukup berperan sebagai organisator dalam kegiatan kelompok tani di Kecamatan Gerung Kabupaten Lombok Barat dikatagorikan ckup berperan bedasarkan pada pernyataan-pernyataan (kriteria).

Tabel 1.4. Sebaran Petani Berdasarkan Skor Peran PenyuluhPertanian Lapangan (PPL) Sebagai Organisator dalam Kegiatan Kelompok Tani di Kecamatan Gerung Kabupaten Lombok Barat Tahun 2018

\begin{tabular}{|c|c|c|c|c|c|c|c|c|}
\hline \multirow[b]{2}{*}{ No } & \multirow[b]{2}{*}{ Kriteria } & \multicolumn{6}{|c|}{ Sebaran Responden Berdasarkan Skor } & \multirow[t]{2}{*}{ Katagori } \\
\hline & & $\begin{array}{c}\text { Tidak } \\
\text { Berperan }\end{array}$ & $\%$ & $\begin{array}{c}\text { Cukup } \\
\text { Berperan }\end{array}$ & $\%$ & Berperan & $\%$ & \\
\hline 1 & $\begin{array}{l}\text { Membantu petani } \\
\text { membentuk kelompok }\end{array}$ & 0 & 0 & 0 & 0 & 45 & 100 & Baik \\
\hline 2 & $\begin{array}{l}\text { Membantu petani dalam } \\
\text { pemilihan pengurus }\end{array}$ & 15 & 33,3 & 6 & 13,3 & 24 & 53,3 & Baik \\
\hline 3 & $\begin{array}{l}\text { Membantu menyususn } \\
\text { jadwal pertemuan }\end{array}$ & 0 & 0 & 11 & 24,4 & 34 & 75,6 & Baik \\
\hline 4 & $\begin{array}{l}\text { Membantu menyusun } \\
\text { pembagian tugas }\end{array}$ & 31 & 68,9 & 9 & 20 & 5 & 11,1 & Tidak Baik \\
\hline
\end{tabular}




\begin{tabular}{|c|c|c|c|c|c|c|c|}
\hline $\begin{array}{l}\text { Membantu menyusun } \\
\text { kegiatan kelompok }\end{array}$ & 35 & 77,8 & 4 & 8,9 & 6 & 13,3 & Tidak Baik \\
\hline $\begin{array}{l}\text { Membantu mengelola } \\
\text { kegiatan kelompok }\end{array}$ & 24 & 53,3 & 6 & 13,3 & 15 & 33,3 & Tidak Baik \\
\hline
\end{tabular}

Sumber: Data Primer Diolah, 2018

Berdasarkan Tabel 1.4. diatas terlihat bahwa sebaran petani yang menilai peran penyuluh sebagai organisator dalam pengembangan kelompok tani berada pada katagori cukup baik. Selanjutnya dari enam kriteria tersebut tiga kriteria termasuk katagori baik dengan penyuluh berperan dan tiga kriteria lainnya berada pada katagori tidak baik dengan penyuluh tidak berperan, yang dimana ternyata peran penyuluh dalam membentuk kelompok termasuk katagori baik dengan sebaran petani paling banyak yakni sebanyak 45 orang dengan persentase $100 \%$, sedangkan sebaran petani paling banyak dengan katagori tidak baik yang menyatakan penyuluh tidak berperan berada pada kriteria peran penyuluh dalam membantu menyusun pembagian tugas kelompok dengan jumlah responden sebanyak 35 orang (77,8\%). Untuk lebih jelas dipaarkan sebagai berikut.

Hasil penelitian menunjukkan penyuluh berperan dalam pembentukan kelompok. Lebih lanjut dilihat dari sebaran petani yang menilai peranpenyuluh dalam pembentukan kelompok seperti tergambar pada Tabel 1.4 atas. Semua responden 45 orang $(100 \%)$ responden menyatakan penyuluh berperan dalam membantu petani dalam membentuk kelompok hal ini dikarenakan penyuluh ikut terlibat dari awal proses pembentukan hingga mendaftarkan kelompok ke balai penyuluhan.

Hasil penelitian menunjukkan penyuluh tidak berperan dalam membantu menyusun pembagian tugas kerja. Lebih lanjut dilihat dari sebaran petani yang menilai peran penyuluh dalam pembagian tugas kerja tergambar pada Tabel 1.4 di atas. Sebagian besar 31 orang $(68,9 \%)$ responden menyatakan penyuluh tidak ikut terlibat dan bahkan tidak mengetahui adanya pembagian tugas kerja dalam suatu kegiatan yang akan petani lakukan dan fungsi dari setiap angota kelompok yang terlibat dalam kegiatan/program kerja yang telah direncanakan. Petani dengan insiatif sendiri melakukan pembagian tugas kerja untuk suatu kegiatan yang akan mereka lakukan yang dimotori oleh ketua dan sekertaris. Akan tetapi penyuluh mengetahui adanya kegiatan atau program yang dilaksanakan oleh petani/kelompok. Penyuluh menyatakan petani menginformasikan kepada penyuluh stelah pembagian tugas terbentuk, sedangkan 9 orang $(20 \%)$ responden menyatakan penyuluh cukup membantu dengan alasan penyuluh mengetahui adanya pembagian tugas kerja yang dilakukan oleh kelompok tani terhadap suatu kegiatan, namun penyuluh tidak tidak ikut terlibat dalam proses pembagiannya, karena petni dianggap lebih mampu dan mengetahui kondisi dan kemampuan dari setiap anggotanya, sementara itu 5 orang $(11,1 \%)$ responden menyatakan penyuluh membantu dalam pembagian tugas kerja, berdasarkan hasil wawancara responden tersebut tidak hadir/terlibat pada saat pembagian tugas kerja sehingga menarik kesimpulan secara subjektif.

Kendala-Kendala yang dihadapi Penyuluh Pertanian Lapangan (PPL) dalam Kegiatan Kelompok Tani di Kecamatan Gerung Kabupaten Lombok Barat Tahun 2018

Penyuluh dalam menjalankan tugasnya tidak selamanya berjalan mulus sesuai rencana, baik itu dikarenakan faktor internal dari penyuluh itu sendiri maupun faktor eksternal yang menimbulkan dampak dalam proses kegiatan kelompok tani. Hasil penelitian menunjukkan bahwa dalam kegiatan penyuluhan kelompok tani di Kecamatan Gerung Kabupaten Lombok Barat terdapat kendala- kendala yang menghambat penyuluh dalam proses kegiatan baik itu dalam peran penyuluh sebagai fasilitator, motivator maupun organisator. Untuk lebih jelasnya dapat dilihat pada Tabel 4.17 berikut:

Tabel 1.5. Kendala-Kendala yang dihadapi Penyuluh Pertanian Lapangan (PPL) dalam Kegiatan Kelompok Tani di Kecamatan Gerung Kabupaten Lombok Barat Tahun 2018

\begin{tabular}{llll}
\hline No & Katagori & Petani (\%) & Penuyuh (\%) \\
\hline 1 & Modal kurang & $27(60)$ & $2(67)$ \\
2 & Rendahnya sumber daya petani & $22(49)$ & $3(100)$ \\
3 & Wilayah kerja penyuluh pertanian lapangan (ppl)yang luas & $8(18)$ & $2(67)$ \\
\hline
\end{tabular}

Sumber: Data primer diolah 2018

Berdasarkan Tabel 1.5kendala-kendala peran penyuluh dalam kegiatan kelompok tani di Kecamatan Gerung Kabupaten Lombok Barat dalam menjalankan fungsinya adalah:

1. Modal 
Berdasarkan hasil penelitian, 2 orang penyuluh (66\%) menyatakan permodalan masih menjadi masalah utama dalam kegiatan kelompok, dimana modal merupakan hal yang penting dalam organisasi karena setiap kegiatan membutuhkan dana untuk kelancarannya. Namun dana yang diberikan pemerintah untuk setiap kegiatan kelompok masih dirasa kurang sehingga petani/kelompok harus mengusahakan sendir untuk mencukupinya. Untuk lebih jelasnya kendala permodalan dalam kegiatan kelompok tani ditinjau dari sisi petani dapat dilihat pada Tabel di bawah ini

Tabel 1.6. Kendala Permodalan yang dihadapi Penyuluh Pertanian Lapangan (PPL) dalam kegiatan Kelompok Tani di Kecamatan Gerung Kabupeten Lombok Barat Tahun 2018

\begin{tabular}{llcc}
\hline No & Katagori & Petani & $(\%)$ \\
\hline 1 & Sumber modal & & \\
\hline & a. Bank & 5 & 18,5 \\
& b. Koprasi & 14 & 51,8 \\
& c. Tetangga & 8 & 29,6 \\
\hline 2 & Jenis modal & & \\
\hline & a. Pengadaan pupuk dan upah tenaga kerja & 27 & 60 \\
\hline
\end{tabular}

Sumber: Data primer diolah 2018

Berdasarkan Tabel 1.6 di atas terlihat bahwa sumber modal untuk usaha tani petani memperoleh dari, bank, tetangga dan koperasi (bank rontok). Menurut sebagian besar responden 14 orang (51,8\%) menyatakan sumber modal paling besar petani yakni dari koprasi/bank rontok karena peminjaman modal dari koperasi (bank rontok) dapat dengan mudah diakses oleh petani karena prosedur peminjaman mudah hanya memerlukan potocopy kartu tanda penduduk (KTP) saja dan proses pengembalian pinjaman bisa ditunda jika petani tidak memiliki uanag saat waktu pengembalian hal tersebut yang membuat petani lebih memilih meminjam di koperasi (bank rontok),sementara 8 orang $(29,6 \%)$ modal yang digunakan berasal dari tetangga, petani memilih untuk meminjam di tetangga karena tanpa persyaratan dan pengembalian pinjaman tidak dipaksakan (kapan petani punya uang saja akan tetapi pinjaman ini sulit didapat), dan 5 orang (18,5\%) memperoleh dana usaha dari bank. Sementara itu untuk jenis modal yang kurang yakni modal untuk pembelian pupuk dan upah tenaga kerja.

\section{Rendahnya Sumber Daya Petani}

Kendala dalam kegiatan kelompok yakni rendahnya sumber daya petani, pemahaman dan tingkat adopsi iovasi petani rendah, sehingga cukup sulit untuk memberikan dampak positif terhadap kegiatan usaha tani. Sebanyak 3 orang (100\%) penyuluh menyatakan rendahnya sumber daya petani ini dipengaruhi oleh faktor usia dimana usia responden rata-rata 45 tahun dan lebih dari 65 tahun dan tingkat pendidikan sebagian anggota kelompok masih rendah yakni 23 orang $(51,1 \%)$ sehingga hal tersebut dapat mempengaruhi daya tangkap dan pengambilan keputusan.

\section{Wilayah Kerja Penyuluh Pertanian Lapanganan (PPL) yang Luas}

Selanjutnya yang menjadi kendala adalah wilayah kerja penyuluh pertanian lapanganan (PPL) yang luas. hal ini dipengaruhi oleh kurangnya tenaga penyuluh pertanian lapanganan (PPL) yang membina kelompok tani pada tiap-tiap desa dan jumlah kelompok yang terdapat pad tiap desa cukup banyak yakni di Desa Giri Tembesi 23 kelompok, Desa Banyu Urip 32 kelompok dan Kelurahan Gerung selatan 19 Kelompok sedangkan jam kerja penyuluh $40 \mathrm{jam} / \mathrm{minggu}$, sehingga penyuluh cukup sulit dalam mengelola secara keseluruhan kegiatan setiap kelompok.

\section{KESIMPULAN DAN SARAN}

\section{Kesimpulan}

Berdasarkan hasil penelitian dan kesimpulan di atas dapat ditarik beberapa kesimpulan antara lain sebagai berikut:

1. Penyuluh berperan sebagai fasilitator, motivator dan organisator dalam kegiatan kelompok tani di Kecamatan Gerung Kabupaten Lombok Barat dengan modus skor gabungan 67 dan dengan sebaran petani sebanyak 35 oranga $(77,8 \%)$ menyatakan berperan dan 10 orang $(22,2 \%)$ petani menyatakan cukup berperan.

2. Kendala yang dihadapi oleh penyuluh dan petani dalam kegiatan kelompok tani di Kecamatan Gerung Kabupaten Lombok Barat yaitu: modal rendah, sumber daya petani masih rendah dan wilayah kerja penyuluh pertanian lapangan (PPL) yang luas. 
Berdasarkan kesimpulan hasil penelitian, maka diajukan saran sebagai berikut:

1. Penyuluh Pertanian Lapangan (PPL) diharapkan untuk lebih membantu petani untuk mengakses modal usaha melalui melalui pengelolaan usaha agar petani tidak perlu meminjam jika modal untuk kegiatan kurang.

2. Penyuluh Pertanian Lapangan (PPL) diharapkan untuk lebih meningkatkan sumber daya petani dalam kelompok melalui berbagai kegiatan pelatihan atau kursus yang dapat meningkatkan pengetahuan, sikap serta keterampilan petani.

3. Pemerintah diharapkan untuk menambah tenaga bantuan dalam bidang penyuluhan pertanian pada tiaptiap desa, sehingga pembinaan kelompok tani menyeluruh dan optimal.

\section{DAFTAR PUSTAKA}

Badan Penyuluhan dan Pengembangan SDM Pertanian. 2016. Database Ketenagaan Penyuluh Pertanian, Jakarta.

Najiah Siti, 2014. Peran Penyuluh Pertanian Lapangan dalam Pembinaan Kelompok Tani di Kecamatan Woja Kabupaten Dompu. Skripsi Fakultas Pertanian Universitas Mataram

Nazir, 2005. Metode Penelitian. Ghalia Indonesia. Jakarta

Septiadi, D. 2019. Analisis Respon dan Faktor-Faktor yang Mempengaruhi Permintaan Beras Indonesia. Agrimor : Jurnal Agribisnis Lahan Kering. Vol 4 (3) 2019: 42-44.

Undang-Undang No.16 Tahun 2006 Tentang Sistem Penyuluh Pertanian, Perikanan dan Kehutanan. Departemen Pertanian. Jakarta.

UPTD Gerung, 2017.Rekapitulasi Penilaian Kelompok Tani di Kecamatan Gerung Kabupaten Lombok Barat Tahun 2017, Kecamatan Gerung

Wirasapta, Karyadi, L. 2016. Penyuluhan dan Komunikasi Pertanian. Pustaka Bangsa. Mataram 